\title{
THEORETICAL BASIS AND SCIENTIFIC VIEWS ON SELF- MANAGEMENT IN THE ORGANIZATION
}

\author{
Iveta Mietule ${ }^{1}$, Oksana Chenchak $^{2}$ \\ ${ }^{1}$ Dr.oec., professor, leading researcher, Rezekne Academy of Technologies, Rezekne, \\ Latvia, e-mail: Iveta.Mietule@rta.lv \\ 2 Master's student in "Management Science", assistant of researcher, Rezekne Academy \\ of Technologies, Rezekne, Latvia, e-mail: oc18002@edu.rta.lv
}

\begin{abstract}
The changes that have taken place in the economy, politics, technology and innovation increase the requirements for management personnel, their professionalism, training and retraining. Organizations cannot take on the development of all the skills of all managers, so maintaining their constant growth and development becomes a necessity for managers and, in general, for any other person who wants to use their time efficiently and make it work. This should become a kind of habit, which is achieved by long work on yourself, the development of perseverance, as well as the ability to think rationally. Nowadays, selfmanagement and self-development of personnel are becoming a factor in the survival of the economy in market conditions, strengthening the position of management in various countries. The aim of the paper is to analyse various research studies in regard to selfmanagement and to give recommendations to improve it. The paper discusses the effective concepts and approaches of various scientists, shows the importance of self-government in work and daily life to achieve the desired success and helps to assess the effectiveness of selfgovernment at the global level. The research used the theoretical information of foreign scientists and Internet resources. The scientific research methods that were used in the research are as follows: literature analysis and synthesis, the monographic method, and content analysis.
\end{abstract}

Keywords: career-controlling, global leader, improving yourself, self-management, successful way.

JEL code: I310, M500.

Received: 20 April 2021 Revised: 27 April 2021 Accepted: 3 June 2021

Published: 10 December 2021

\section{Introduction}

Many people want to make work more efficient, high quality and with less cost and power. Self-management with all its components helps to get the best result, reduce the load and feel much better, be more successful in all aspects. Today there are many types of management, but you need to start with yourself, namely to understand and know self-management. Selfmanagement and today's attention to teamwork, new opportunities, and self-governing working groups give people the advantage to take care of themselves at work (Meina Zhu et al., 2020).

Self-management, as a new direction in modern management, is created relatively recently, but is developing very intensively. In the United States, 
which is the ancestor of self-management as a science, almost all higher education institutions study "Self-Management" (Eitel et al., 2020).

Managing an organization or having your own business in our changeable times is a complex job that cannot be successfully accomplished by simple, learned formulas. The leader must understand the general truths and their modern variations that make situations different from each other, also understand and take into account critical factors, internal and external variables.

In a broad sense, self-management requires employees to think, feel, and act in a way that promotes the realization and improvement of the individual employee (Costea et al., 2008; Manz, Sims, 1989; Thomas, 2002). The term is ambiguous, and in most discussions self-management refers to a combination of behaviours that focuses on how people govern themselves in their work and their lives. The essence of modern management, on the one hand, is that it comes from the individual, his/her needs and goals, accumulated knowledge, experience and achievements of scientific and technological progress. On the other hand, it is a creative and intensive application of information technology.

The aim of the paper is to identify the importance of self-management in an organization and prospects for the future if implementing this action.

The tasks of this paper is to clarify the theoretical aspects of the understanding of self-management; consider different concepts from the point of view of well-known scientists in the field of management; identify the importance of self-management at work, in everyday life and in achieving success; evaluate the effectiveness of self-management of global leaders.

The novelty of the research stems from the two important points. With increasing competition, the scale of various changes in entrepreneurship, businesses, which require the development of new skills and the coexistence of different types of management, combats the possibility of self-retardation. And self-management is a prerequisite for survival in the labour market. In order to succeed, you need to be able to manage yourself. Also, technology is changing the nature of work so that it is more common to operate in what may be called an «electronic cottage» (DeNisi, Griffin, 2001). Nowadays, this is quite relevant because of the pandemic. Most of the people work, study and just spend a lot of time at home. Under these arrangements, self-control and self-management are needed in this environment.

The scientific research methods that were used in the research are as follows: literature analysis and synthesis, the monographic method, and content analysis. The paper used the theoretical views of foreign scientists and Internet resources. 


\section{Self-management conceptual approaches}

The concepts of self-management put forward are based on a certain idea, proceeding from the system of techniques and perceptions of work itself for realization of this idea. The most famous are the concepts of the following scientists: L. Seiwert (1989), M. Woodcock and D. Francis (1991), B. and H. Schwalbe (Швальбе, 1993), V. Andreev (Андреев, 1995), 0. Khrolenko (Хроленко, 1996) (Table 1).

\section{Table 1 Basic concepts of self-management from the point of view of different scientists (compiled by the authors)}

\begin{tabular}{|c|c|c|}
\hline $\begin{array}{c}\text { Author of the } \\
\text { concept }\end{array}$ & The main idea & Understanding of self-management \\
\hline L. Seiwert & Save time & $\begin{array}{l}\text { Consistent and purposeful use of proven } \\
\text { methods of work in everyday practice in order } \\
\text { to optimally and meaningfully use your time. }\end{array}$ \\
\hline $\begin{array}{l}\text { M. Woodcock } \\
\text { and D. Francis }\end{array}$ & $\begin{array}{l}\text { Overcoming your } \\
\text { own limitations }\end{array}$ & $\begin{array}{l}\text { A comprehensive way to test your capabilities } \\
\text { and limitations and find real ways to develop } \\
\text { personal and business qualities. }\end{array}$ \\
\hline $\begin{array}{l}\text { B. and H. } \\
\text { Schwalbe }\end{array}$ & $\begin{array}{c}\text { Achieving } \\
\text { personal } \\
\text { business success }\end{array}$ & $\begin{array}{l}\text { Achieving a business career through self- } \\
\text { knowledge and self-improvement of their } \\
\text { business qualities. }\end{array}$ \\
\hline V. Andreeva & $\begin{array}{l}\text { Self-development } \\
\text { of creative } \\
\text { personality }\end{array}$ & $\begin{array}{l}\text { Ability to continuous self-development and self- } \\
\text { realization in one or more types of professional } \\
\text { activity through a psychological mechanism. }\end{array}$ \\
\hline O. Khrolenko & $\begin{array}{l}\text { Improving the } \\
\text { personal culture } \\
\text { of business life }\end{array}$ & $\begin{array}{l}\text { Increasing business potential by raising the } \\
\text { level of business culture in its various aspects. }\end{array}$ \\
\hline
\end{tabular}

Thus, hardly any of the considered concepts of rational organization of time, personal constraints, achieving business success, self-development or culture of business life can be proposed as a sufficiently justified and effective methodology for managing one's own career. But each of them offers many useful methods, techniques, tips and tricks that can be used in selfmanagement of a business career and also in life. All of these concepts focus on success as a result and provide strong motivation and business potential in order to increase chances and career prospects.

\section{System of elements for understanding self-management}

Robert Kelly includes a full chapter on self-management in his book How to Be a STAR at Work (Kelley, 1998). His research highlights the following key elements of self-government: 
- learning to support the goals of the organization and your own goals throughout your life;

- making sure that your projects add value to the organization;

- developing your personal productivity skills to manage your time and responsibilities;

- building extensive personal networks that allow you to use knowledge inside and outside the organization to solve complex problems;

- accepting changes and rethink both organizational structures and definitions of work as new opportunities arise (Suess, 2015).

Successful employees directly manage their work and careers. By placing high value on the organization, stars are given more opportunities to choose which projects to work on and instinctively develop new skills to further their career prospects (Suess, 2015).

Well-known psychologist K. Keenan (2015) offers her view on selfmanagement. She considers the following components of successful selfmanagement: self-assessment, ability to achieve goals, ability to manage stress, ability to find common ground with others, show endurance and selfcontrol, a positive life position. It is these factors that allow you to effectively manage yourself and get good results such as well-being and achievement of goals. T. Bryant (2004) considers self-discipline as a process of mental selfmanagement, which allows a person to mobilize all the resources and opportunities to achieve consciously set goals.

The regular solution of different types of tasks and problems can be interpreted as a series of functions that are interdependent and performed in a specific order. In terms of the sequence of basic functions, the symbol mechanism is divided into six stages (Seiwert, 1989):

1. The goal's aim is to assess and create personal goals;

2. Planning entails the development of plans and alternate solutions for the company's operations;

3. Taking individual cases into consideration;

4. Implementation and organization - compiling the daily schedule and organizing the personal labour process in order to carry out the assigned tasks;

5. Control, self-control and performance tracking (if applicable, target adjustments);

6. Knowledge and communication is a process that is unique to some degree to all functions, as communication and information sharing are required at all stages of self-management.

Performing these functions necessitates the use of specific methods and techniques, which allows you to achieve results that contribute to success and bring you closer to your goals. Examine the most popular ones and see 
what self-management functions they help with and what advantages they provide (Figure 1).

Gsing techniques such as SWOT analysis, proper goal setting, and
the selection of a behavior strategy. These methods allow you to
identify flaws and focus your efforts on eliminating them.

\section{Fig.1 Tools and methods of self-management for the implementation of the functions (compiled by the authors, based on Seiwert, 1989)}

Based on the mentioned functions, L. Seiwert (1989) refers to the advantages of self-management: performing work at less cost, better work organization and results, less rush and stress, more job satisfaction, great motivation for work, advanced training, a lower workload, fewer mistakes in performing their functions. L. Seiwert (1989) considers the main advantage to be the rational use and conservation of the most scarce and important personal resource of his own time.

Most authors use the approach to defining the functions of selfmanagement by L. Seiwert (1989), but some scientists offer other classifications. Thus, V. Kolpakov (Колпаков, 2008) proposes to distinguish between the functions of strategic self-government (strategic decisionmaking, self-government, self-development, self-education, etc.); functions of daily self-government (informational, goal-setting, decision-making, planning, organization, self-motivation, self-regulation, self-control, etc.). Also, S. Shtapauk (Штапаук, 2011) offers functions of self-management such 
as goal setting, planning, organization and control and adds a specific function of self-management such as self-awareness. According to the authors, the allocation of the function of self-awareness is to some extent justified because it is the ability of a person to realize him/herself as a person and covers such important elements as self-knowledge, self-esteem, selfattitude and self-understanding.

\section{Assessment of leadership development at the global level through self- management}

People who are in touch and can control their emotions create an atmosphere of trust for employees. Therefore, such a leader is realized, they understand that $\mathrm{s} /$ he can be counted on and whose behaviour is consistent and $\mathrm{s} / \mathrm{he}$ has global goals. This has a cascading effect for all employees. Calmness at the top means calmness at all levels, which leads to reduced anxiety and higher productivity. Self-leadership is the first level of leadership and applies to anyone, regardless of the position. This allows a person to realize the potential, building a stable foundation on which to make daily decisions - professionally and personally. Losing a strong sense of selfgovernment or a lack of self-management can make people feel uncontrollable, depressed and out of focus (Ivanonkiv, 2014).

Leaders' self-development is defined as "the process by which leaders take personal responsibility for initiating, supporting, and evaluating the growth of their own leadership capabilities and within their conceptual framework for leadership behaviour" (Boyce et al., 2010). Self-development is a form of continuous self-learning and self-management.

The precondition for the development of world leadership is the global economy. The modern global economy has created a more complex and dynamic environment in which most companies compete effectively for sustainable development. Large and small companies have increased the number of their foreign suppliers, partners, employees, shareholders and customers. Connected with world leaders (or leaders who want to become global leaders), this is a global environment that has not only changed the business but also changed the way we do business to compete successfully (Caligiuri, Sinha, 2010).

It is obvious that globalization and the new business reality also place demands on world business leaders who must be able to successfully perform their work in a cross-border and multicultural environment. A global leader identified by managers working internationally must effectively manage a complex, diverse, and ambiguous global environment (Bartlett, Ghoshal, 2003; Caligiuri, Di Santo, 2001). To reach this level, you need to master self-management extremely well to go to the top of the world. 
To become a world leader, good manners and self-management in their strength and organizational aspects are not enough, it is necessary to learn to be an adept at culture, adapting to a multicultural context. Cultural agility is the ability of people or organizations to move quickly, comfortably, and successfully from one cultural context to another (Caligiuri, 2007; Caligiuri, Tarique, 2008). Researchers claim that for a global leader, cultural agility is the ability to succeed in a multicultural environment, allowing them to change their behavioural responses to the needs of the cultural environment. Managers who are culturally receptive can accurately assess differences in behaviour, attitudes, and values between themselves and others, and they know how and when to apply cultural knowledge and behaviour appropriately (Caligiuri, Tarique, 2008).

The growing demand for future global leaders, combined with firms' inability to keep up, presents an opportunity for those who want to take control of their careers and self-develop their global leadership competencies (Hirschi and Koen 2021). From the perspective of organizations, self-initiative development can increase the number of talents without putting additional strain on the organization's resources. Despite the high demand for global leadership, not everyone is suited for it, and not everyone will benefit from global development experience. When the right people with the right knowledge and potential are interested in the right growth opportunities, the outcome is an improvement in global performance tasks and management activities (Caligiuri, Sinha, 2010).

Individuals should initiate cross-cultural preparation and growth opportunities, such as language and cultural training, and self-initiating an international assignment, to be successful global leaders. Those who are inclined and motivated to become global leaders will invest in themselves by initiating and participating in high-contact global leadership development opportunities. Future business leaders will be in high demand, and individuals who want to take charge of their careers and improve their global leadership and self-management skills will have plenty of opportunities (Hirschi, Koen 2021).

\section{Conclusions and suggestions}

Currently, for the organization's success, its employees must be able to solve an increasing number of different tasks in a short period of time. One of the ideas of self-management is the use of a set of proven methods and skills in everyday practice to optimize the use of their time and increase efficiency. Self-management may be useful if a few simple principles are followed, regardless of the purposes for which it is used: 
- The first step in self-management is to set specific goals. A clear picture of the outcomes is provided by a well-defined objective. At the same time, you must understand that the overall objectives can and should be changed over time, as the external environment changes.

- The second is to plan ahead of time.

- The third is decision-making, which means deciding which of these cases should be made first and which should be made second.

- The fourth is implementation and organization, which entails planning and sticking to a work schedule. The basic organizing principle of the working day is that work must obey me and not the other way around.

- The fifth is control. When a result is received, it is compared with the goal; if the result is as expected, the labour process is on track; if not, adjustments must be made during the labour process or the goals must be reviewed. As a result, having control over the outcomes aids in the optimization of the labour process.

Self-management is the ability to extract, store, develop, and rationally use one's own resources in order to be successful and self-sufficient. The research supports the conclusion that self-management is superior to more conventional types of management because self-managed organizations are more efficient and creative, as well as fairer and have greater degrees of autonomy.

\section{References}

1. Bartlett, C., Ghoshal, S. (2003). What is a global manager? Harvard Business Review, August, 101.

2. Boyce, L.A., Zaccaro, S.J., Wisecarver, M. (2010). Propensity for self- development of leadership attributes: understanding, predicting, and supporting performance of leader self- development. Leadership Quarterly. 2(1), 159-178. https://doi.org/10.1016/j.leaqua.2009.10.012

3. Bryant T. (2004). Self-Discipline in 10 Days. How to Go from Thinking to Doing. Seattle, Wash: HUB Publishing, 160.

4. Caligiuri P., Sinha R. (2010). Edward Elgar Publishing, Inc. ISBN 9781848443235. 3429

5. Caligiuri, P. (2007). The Self-Assessment for Global Endeavors - Global Business Leaders (The SAGE- GBL). New York: RW- 3

6. Caligiuri, P., Tarique, I. (2008). Developing managerial and organizational crosscultural capabilities, in C. Cooper and R. Burke (eds). The Peak Performing Organization. Abington, UK: Routledge Publishers, 234-51.

7. Caligiuri, P.M., Di Santo, V. (2001). Global competence: what is it, and can it be developed through global assignments? Human Resource Planning, 3, 27-35.

8. Costea, B., Crump, N., Amiridis K. (2008). Managerialism, the therapeutic and self in contemporary organizing. Human Relations, 61(5), 661-685. https://doi.org/10.1177/0018726708091763 
9. DeNisi, A. S., Griffin, R. W. (2001). Human Resource Management. Boston, MA: Houghton Mifflin.

10. Eitel, A, Endres, T., Renkl, A. (2020). Self-management as a Bridge Between Cognitive Load and Self-regulated Learning: the Illustrative Case of Seductive Details. Educational Psychology Review, 32, 1073-1087. https://doi.org/10.1007/s10648020-09559-5

11. Hirschi, A., Koen, J. (2021). Contemporary career orientations and career selfmanagement: A review and integration. Journal of Vocational Behavior, 126.

12. Ivanonkiv, 0. (2014). Why does self-management important for leaders. Матеріали XVIII наукової конференції ТНТУ ім. І. Пулюя, 209.

13. Keenan, K. (2015). Manage yourself: Learn How to Look After Your Most Valuable Asset - You. Pocket Manager (2nd ed), 72.

14. Kelley, R. E. (1998). How to Be a STAR at Work: 9 Breakthrough Strategies You Need to Succeed. New York: Times Books.

15. Manz, C., Sims H. (1989). Superleadership: Leading others to lead themselves. New York: Prentice Hall.

16. Meina, Zhu, Curtis, J., Bonk, Min Young Doo. (2020). Self-directed learning in MOOCs: exploring the relationships among motivation, self-monitoring, and selfmanagement. Educational Technology Research and Development, 68, 2073-2093. https://doi.org/10.1007/s11423-020-09747-8

17. Seiwert, L. J. (1989). Managing Your Time. Business Action Guides. Publisher: Kogan Ltd., 80.

18. Suess, J. (2015). Power to the People: Why Self-Management Is Important. Retrieved from https://er.educause.edu/blogs/2015/9/power-to-the-people-why-selfmanagement-is-important

19. Thomas, K. W. (2002). Intrinsic motivation at work: Building energy and commitment. San Francisco, CA: Berrett-Koehler.

20. Woodcock, M., Francis, D. (1991). The Unblocked Manager: A Practical Guide to SelfDevelopment

21. Андреев, В. И. (1995). Саморазвитие менеджера: научное издание. Москва: Народное образование, 158

22. Колпаков, В. М. (2008). Самоменеджмент. Навч. посіб. для студ. ВНЗ. Київ: ДП Видавничий дім "Персонал". 528.

23. Хроленко, А. Т. (1996). Самоменеджмент. Для тех, кому от 16 до 20. Москва: Экономика, 136.

24. Швальбе, Б., Швальбе Х. (1993). Пер. с нем. М.: АО Издат. группа Прогресс-Интер, 228, 14.

25. Штапаук, С. С. (2011). Самоменеджмент керівника. Навч. посіб. Луганськ: Віртуальна реальність, 140. 